\title{
ANCIENT RELIGIONS IN THE CONTEXT OF CULTURAL TYPES
}

Mimi Lobell

In this paper, I am very briefly presenting a typology of cultures, which spans from prehistory to the present. I have been developing this theory for over ten years and have completed a book manuscript on it. Here, I will necessarily be limited to outlining the theory and giving a synopsis of the six cultural types I have identified: the SENSITIVE CHAOS of the Palaeolithic hunter-gatherers, the GREAT ROUND of the Neolithic and Early Bronze Age farmers, the FOUR QUARTERS of the Bronze and Iron Age Chiefdoms, the PYRAMID of the nation state, the RADIANT AXES of the empire, and the GRID of the commercial-industrial network.

I will suggest only one or two direct applications to the subject of the conference, but many more are clearly implied. For those who wish to pursue this further, more details are available in my article, "Spatial Archetypes" in REVISION (1983).

I hope that this typology of cultures, which focuses on their religions, mythologies, and world views, can provide researchers with a useful context within which to evaluate archaeological evidence and other fragmentary information.

\section{THE THEORY}

This theory of cultural types originated in my observation that many cultures widely separated in space and time have produced very similar architectural forms. Because it is so familiar, the pyramid can demonstrate the pervasive nature of these forms. As we can see in these examples, it has appeared in nearly all parts of the world:

1. The Giza Pyramids, Egypt. 2500 B.C.

2. The Pyramid of the Sun, Teotihuacan, Mexico. 150 B.C. 750 A.D.

3. The Ziggurat of Ur-Nammu in ancient Sumer. 2100 B.C.

4. Pusa Peak, China (a natural mountain enhanced by a Buddhist shrine with 108 steps).

5. A Classic Mayan pyramid, Tikal, Guatamala. 
6. The Bakheng temple mountain, Angkor, Kampuchea. 9th c. A.D.

7. The Mount Li Tomb, Xian, China. About 210 B.C.

8. The Borobudur Stupa, Java. 9th c. A.D.

9. Pyramid of the Niches, Classic Period at El Tajin, Mexico.

10. A pre-European Royal Tomb at Apia, Samoa.

We can analyze the recurring form motifs in world architecture the way a comparative mythologist would analyze a mythic motif in world mythology - for instance, as Joseph Campbell did in The Hero with a Thousand Faces (1949), and Erich Neumann in The Great Mother: Analysis of the Archetype (1955). This enables us to differentiate their underlying structural similarities, which are universal, from their surface colorations, which vary from region to region and culture to culture.

The structural similarities in the recurring forms in world architecture point to their significance as archetypes. I find this a useful concept, not as an argument against cultural diffusion for I do not think it is an "either-or" issue, but rather as a model for the relationship between the universal and the particular in the various forms of cultural expression. There may be surface differences in the appearance or use of a type of structure from culture to culture at the same time that there are archetypal similarities of form and meaning. The pyramid can be planar or stepped, and it can serve as temple, tomb, or reliquary, but it is nearly always a model of the sky-aspirant World Mountain stretching between Heaven and Earth about the numinous axis mundi.

Without denying the importance of their differences, my study focuses on the similarities in the recurring forms in world architecture in order to penetrate their archetypal nature. Each spatial archetype thus revealed points to a different world view working powerfully within a culture to bind all its forms of expression into a coherent whole. Thus, its art, mythology and religion, architecture and town planning, social and economic system, prevailing family structure, moral code, etc., all coordinate to reinforce the culture's archetypal. structure of meaning.

As we might expect, each archetypal form is consistently found in the same general social context. For example, whether in Egypt, Mesopotamia, Asia, Oceania, or the Americas, the pyramid consistently arises as an architectural form shortly after the social 
structure has coalesced into nation or city states governed by a dynastic succession of rulers, who are usually divine and mediate the axis between Heaven and Earth on behalf of their subjects. Once we recognize this pattern, we can see that the Gothic cathedrals and certain Greek temples are variants of the Pyramid archetype.

In Pyramid cultures, society is structured into a hierarchical pyramid of classes. Often this is mirrored in a concept of tiered Heavens and Hells to which one goes after death depending on one's station in life and the nobility of one's soul. Finally, the cosmos itself is mythically represented as the World Mountain modeled by the architectural pyramid. This Mountain may be the birthplace or abode of the gods and goddesses as in the "primeval hill" in Egypt and Mount Olympus in Greece, or it may be a complete conceptual model of the cosmos as in Mount Meru (Govinda 1976) in India and the Mayan imago mundi (Thompson 1970). In any case, the World Mountain models the cosmic pattern of the social order and of the purpose and meaning of life on earth.

What emerges from these efforts to let architecture, comparative mythology and religion, psychology, archaeology, and anthropology shed light on one another are models of cultural types, which usually succeed one another as stages of development in any given geographical area. There are indications in the research of Jean Piaget (1960, 1967), Erich Neumann (1954), and others that these cultural stages parallel stages of individual psychological development. I must omit most of these intriguing parallels in this brief paper, but they are more fully presented in my ReVISION article.

I feel strongly that each cultural type should not be seen as an inevitable stage in an inexorable evolution toward the type of culture we in the West enjoy today. Rather, it is a completely distinct way of life in its own right, and each type has a fundamentally different world view.

\section{THE TYPES}

I have identified six major spatial archetypes, which I have termed the Sensitive Chaos, the Great Round, the Four Quarters, the Pyramid, the Radiant Axes, and the Grid. Each is associated with a different cultural type. This does not mean that a spatial form can appear only in its associated culture, but rather that it is dominant and has its truest meaning in that type of culture. 
1. The first type, the SENSITIVE CHAOS, (for the origin of the name of the archetype, see Schwenk 1965), is seen among Palaeolithic hunter-gatherers living in nomadic, egalitarian bands. Based on the meandering spiral that has no apparent geometric order or centralizing axes, it expresses the way of life of a people who do not build permanent architecture, and whose view of the world is of a fluctuating unified field of being in which one life form can transform into another through magical or shamanic states of mind.

This cultural type developed and prevailed in the first few million years of human evolution up to about 15,000 B.C. Among the precious few Sensitive Chaos cultures extant today are some Australian Aborigines, the Tasaday of the Philippines, and the Kung San and Pygmies of Africa.

2. The second type, the GREAT ROUND (name origin: Neumann 1955: 211-239), most concerns the subject of this conference and is associated with Neolithic and early Bronze Age farmers. Rooted in the land, they build permanent dwellings, shrines, granaries, and collective graves. Indeed, most megalithic structures can be credited to them. The Great Round as a circular form is often expressed in stone circles, passage mounds, sacred caves, and sanctuaries, although there are also non-circular structures. The spiritual focus is on the Great Goddess, and her sacred Womb-Cavern is a prevalent form motif that becomes the prototype for the holy-of-holies of nearly all later religions.

Worship of the Great Goddess in her various forms fosters the sensibilities and values of the feminine principle, much as the worship of male gods fosters the sensibilities and values of the masculine principle. Great Round cultures are female-centered, which does not mean that they simply reverse today's sex roles. It means that they have or had a fundamentally different world view, and consequently, fundamentally different social systems, institutions, religions, artifacts, settlement patterns, building types, technologies, etc.

In keeping with the female-centeredness of the Great Round, matrilineal families are common, and relatively egalitarian social structures persist, with little evidence of royal burial or status differentiated housing. The archetype is further amplified in the holistic psychological state which seems to prevail, judging both from the peacefulness prehistoric Great Round cultures sustained for thousands of years - which is nearly miraculous considering how commonly war is assumed to be inherent in human nature - and from their cyclical view of time based on continually recurring agricultural seasons. 
Unlike the relatively static hunting-gathering cultures, the peoples of the Great Round exhibit a dynamic inventiveness, seen typically in the development of pottery, agriculture, animal domestication, metallurgy, astronomy, and permanent villages and towns.

Examples of Great Round cultures and sites include the Maltese temples and rock-cut tombs, the pre-Greek cultures of the Aegean, Khirokitea on Cyprus, most of the cultures discussed by Marija Gimbutas in The Gods and Goddesses of Old Europe (1974), the Boyne Valley culture in Ireland, Predynastic Egypt up to the Gerzean, Mesopotamia into the early Ubaid period, Çatal Hüyük in Anatolia, the Yang Shao culture in China, and the Jomon of Japan. Certain later Bronze Age cultures such as Minoan Crete and the Indus Valley Civilization also display a predominance of Great Round characteristics. Among contemporary Great Round cultures can be numbered the Hopi and Pueblo Indians of the American Southwest.

3. The third type is the FOUR QUARTERS (name origin: Perry 1966), seen in the warlike hierarchical chiefdoms of the Bronze and Iron Ages. The spatial archetype is represented by the cardinal axes bounded by a square, which is a major spatial motif in forts, temples, and walled cities. The cosmos is divided into quarters, and everything - including the seasons, colors, elements, castes, past ages, and human attributes - is aligned along the cardinal axes.

Spiritual life is centered on the archetypal "Lord of the Four Quarters", a heroic male god, usually of thunder and war like Zeus, Thor, and Indra, who rules from the central position in a hierarchical pantheon. He is mirrored by the chieftain as the central authority in a caste society, and by the father as the head of the new patriarchal family. The analog in individual development is the rise of the ego as the central reference point in the psyche. Other common mythical themes concern metallurgy and the blacksmith (Eliade 1978), the dragon-slayer (Neumann 1954: 131-133, 152-169), and the conquest and domestication (e.g. through marriage) of the goddesses of the older Great Round cultures (Graves 1.960: 13-24).

Examples of the Four Quarters include Homeric Greece, the Etruscans, Bronze and Iron Age Indo-European language-speaking cultures in general, the Ubaid period in Mesopotamia, early Vedic India, the Shang and Chou dynasties of China, the Israelite tribes before David, and the Late Preclassic cultures of Mesoamerica; and I would also cite the "disk idols" of Malta's Tarxien cemetery culture as illustrations of the Four Quarters. 
4. The fourth type is the PYRAMID, which, as we saw earlier, is associated with the nation or city state. As a "stage of cultural development", this is usually considered the Classical Period or "Golden Age" when a civilization reaches the height of its artistic and architectural florescence. Pyramid cultures are characterized by dynastic theocratic rule; reverence for the World Mountain; the building of architectural pyramids; and all the attributes of statecraft in sluding standing armies, intensive agriculture, urban centers, and class-structured societies.

A growing dualism, expressing an increasing alienation between ego and Self (Edinger 1972), generates a spiritual emphasis on the logos principle. This can be seen in the proliferation of writing and mathematics; and in the idea that the universe is secretly ordered according to divine laws, mystical geometric relationships, sacred names, and numbers imbued with magical power, all of which are accessible only to the ruler and his elite priesthood. The operative maxim is "as above, so below", and the ruling dynasty is mandated to insure microcosmic harmony. Usually the dynastic tribal deity reigns at the apex of a syncretic state religion centering on the divine (or divinely inspired) ruler's ritualistic and symbolic mediation of the axis mundi - that spiritual axis between Heaven and Earth paralleled by the psychological axis between the ego and the Self (Edinger 1972: 5).

Examples of the Pyramid type include Old Kingdom Egypt, Sumer, the Kingdoms of David and Solomon in the Levant, Classical Greece, the Ch'in (Qin) through Sung Dynasties in China, the Buddhist and Hindu Dynasties in India, the Toltecs and the Maya, the Khmers at Angkor, the Sailendra Dynasty in Java, and the Gothic cathedral builders of medieval Europe.

5. The fifth type is the RADIANT AXES empire, which subsumes a number of nation states. The sun, with its seemingly infinite rays of power is a dominant image, mirrored for instance in networks of roads radiating from palaces like Versailles or from capitals such as Imperial Rome or Cuzco, the Peruvian capital of the Incan empire.

The gigantism and ego-inflated quality of this type are seen in colossal sculptures and structures such as those at Abu Simbel and Karnak (Giedion 1964: 25-26, 385), and in propagandistic murals or bas reliefs such as those at Persepolis, capital of the Persian Empire. A strong vertical axis is commonly embodied in the obelisk form, which can symbolize a ray of the sun. 
In the Radiant Axes, a ceremonially pompous, spiritually empty state religion tends to prevail, focusing on the Sun God: Amon-Ra in New Kingdom Egypt, Apollo or Helios in Greece, Tonatiuh among the Aztecs, Inti in the Incan empire. The importance of the sun is illustrated also in Louis XIV's epithet "the Sun King" and in the acceptance of Copernicus's heliocentric theory of the universe just as Europe entered her Age of Imperialism.

6. Empires usually end abruptly through violent revolutions, which establish the last archetypal form: the GRID of the international, post-imperialistic commercial-industrial networks. These are characterized by secularism, bureaucracy, mercantilism, eclecticism, decadence, nihilism, and mass production industries (in part, Spengler 1939). The grid form appears in the layouts of worker's housing, bureaucratic land divisions, colonial cities, military camps, market and factory towns, assembly lines, office buildings, and industrialized farms. And, like the spatial archetype itself, the social system seeks to decentralize power, whether through republicanism or communism, socialism or democracy.

Rarely do Grid cultures create new forms; rather, they repeat, refine, standardize, and mass-produce old forms borrowed from previous eras and more creative cultures. They may, however, accomplish impressive feats of engineering, like those of the Roman, Incan, and modern Western civilizations.

Psychologically, the Grid parallels the deflated ego, bringing a sense of anonymity and despiritualization. Religion can become a freefor-all with eclectic experimentation, charismatic cults, and desperate zealotry. Whether in society, the psyche, or the spirit, the center cannot be found. Ultimately, however, the Grid can foster the perception that all the archetypal gods and goddesses, heroes and demons are within oneself, and religion then becomes the inner path.

Grid cultures include Ptolemaic Egypt, Hellenistic Greece, the late Roman Empire, China from the Manchu Dynasty to the present, and of course contemporary Western culture.

\section{CONCLUSIONS}

It is often possible to trace the whole sequence of archetypes in one civilization. For instance, in the Aegean, the Sensitive Chaos would have prevailed up to the time of the first agriculturalists about 6500 B.C. Then the Great Round began, with its relatively peaceful, 
goddess-centered way of life embracing the first farmers (such as those living at Nea Nikomedeia by about 5800 B.C.). Typified by the Early Cycladic culture, the Great Round continued in many ways even through the Minoan civilization, though signs of defensive fortifications and social hierarchy began appearing at sites such as Dhimini and Troy in the fourth millennium B.C. The Indo-European invasions from at least 2000 B.C. or earlier clearly initiated elements of the Four Quarters, but the true turning point was the shift of power around 1500 B.C. from peaceful Minoan Crete to warlike Mycenae. The Four Quarters - Archaic Greece's heroic, Homeric Bronze and Iron Ages - continued until the flowering of Classical Greece in the fifth century B.C. With its Olympian mythology, city states, Athenian Acropolis, and growing logos principle, Classical Greece was a true Pyramid culture, though it was not theocratic and did not build pyramids. By the time of his death in 323 B.C., Alexander the Great had established a Radiant Axes empire that had spread Greek civilization throughout the known world. The subsequent Hellenistic Period represented the Grid, with Greece being subsumed by Rome by 146 B.C.

A most important use of the theory, and the reason I wished to present it at this conference, is that it offers contextual models in which to interpret data and artifacts. For example, we can see that the Neolithic Maltese cultures responsible for the temples and rock-cut tombs strongly exhibit Great Round characteristics - including megalithic structures, peacefulness, goddess-worship, and collective burial. There is little or no physical evidence for the hypothesis advanced by Colin Renfrew (1979) that they were organized around chieftains (i.e., that it was a Four Quarters type of culture as were the Easter Island and Polynesian cultures he cites for comparison). This hypothesis seems to be based mainly on the assumption that no society could build such major structures without the central organizing authority of a chieftain. Renfrew writes, "The temples of Malta, for instance, are too big to have been the product of single small and independent farming villages" (1979: 156).

The same chieftain hypothesis is still sometimes advanced for other sites such as Silbury Hill, Newgrange, and the early stages of Stonehenge, which also clearly fall within the Great Round context. (In this regard, it would be useful to examine the Anasazi culture of the American southwest, which accomplished quite complex feats of building, astronomy, irrigation, and road-making within an egalitarian Great Round context, presumably acting on a consensus 
basis as do their descendents, the contemporary Hopi, Zunı, and Pueblo Indians).

By definition, prehistoric religion is lacking the written literature that would elucidate its nature and meaning. Thus it has been highly vulnerable to the assumptions and biases of researchers, most of whom have lived in Radiant Axes and Grid cultures. We can see this, for instance, in the use of the term "fertility cult" to describe the prehistoric religion of the Great Goddess. A "cult" is usually a small, possibly fanatic, fringe group in religion of the type often seen in Grid cultures. But there is profuse evidence that the religion of the Great Goddess was the main religion practiced nearly universally in prehistory for thousands of years.

The term "fertility" stresses only one aspect in a religion that also dealt with death, prophecy, calendrics, and astronomy, among other things. Indeed, the Great Goddess provided a complete world view different from our own. And, like women in our culture, the Goddess has suffered the trivialization of being seen merely as a fertility figure, or a doll or plaything, or a "pin-up" for sexual arousal, or simply a "fat lady".

The models outlined in this paper can lead to a new clarity by helping us to understand other cultures, including their artifacts and religions, in full recognition of their world views. And we can benefit greatly from the sources of meaning offered by comparative mythology and religion, psychology, and the studies of architectural symbolism that have contributed to this typology.

\section{Summary}

A cross-cultural study of spatial archetypes in architecture, town planning, art, mythology, cosmology, and social structures from prehistory to the present reveals six models of cultures, each with a distinct world view and religion:

1) The SENSITIVE CHAOS of Palaeolithic hunter-gatherers: "the world is one within the animal spirits"

2) The GREAT ROUND of Neolithic and Early Bronze Age farmers: "the world is one within the Great Goddess"

3) The FOUR QUARTERS of Bronze and Iron Age hierarchical chiefdoms: "the world is centered on the Lord of the Four Quarters" 
4) The PYRAMID of Classic Period nation or city states and theocracies: "the world is the Sacred Mountain of the FatherGod"

5) The RADIANT AXES of Postclassic empires: "the world is.ruled by the Sun"

6) The GRID of post-imperialistic commercial-industrial networks: "the world has no center".

This typology of cultures and religions can enhance our understanding of the ancient world - especially of the ancient Mediterranean - giving us a useful context in which to evaluate archaeological evidence and fragmentary data.

\section{Résumé}

Une étude inter-culturelle des archétypes spatiaux en architecture, urbanisme, art, mythologie, cosmologie et sociologie des structures sociales de la préhistoire jusqu'à nos jours, révèle six modèles de cultures caractérisés chacun par une vision du monde et une religion distinctes:

1) Le CHAOS SENSIBLE des pratiquants de la chasse et de la cueillette de l'ère paléolithique: "le monde est un avec l'esprit des animaux"

2) Le GRAND CERCLE des agriculteurs de l'ère néolithique et du début de l'Age de Bronze: "le monde est un avec la Grande Déesse"

3) Les QUATRE QUARTIERS des clans hiérarchiques de l'Age de Bronze et de l'Age de Fer: "le monde a pour centre le Seigneur des Quatre Quartiers"

4) La PYRAMIDE des états-nations, des cités-états et des théocraties de la Période Classique: "le monde est la Montagne Sacrée de Dieu-le-Père"

5) Les AXES RAYONNANTS des empires post-classiques: "le souverain du monde est le Soleil"

6) La GRILLE des réseaux commerciaux et industriels postimpérialistes: "le monde n'a pas de centre".

Cette typologie des cultures et des religions peut accroître notre compréhension du monde antique - et surtout du monde antique méditerranéen - en nous fournissant un contexte utile au sein duquel évaluer les preuves archéologiques et les données fragmentaires. 
BACON, Edmund

1974 - The Design of Cities, Revised Edition, New York(Viking Press).

CAMPBELL, Joseph

1949 - The Hero with a Thousand Faces, Bollingen Series XVII, Princeton (Princeton University Press).

CASSIRER, Ernst

1944 - An essay on Man, New Haven (Yale University Press).

EDINGER, Edward F.

1972 - Ego and Archetype, New York (G.P. Putnam's Sons).

ELIADE, Mircea

1964 - Shamanism: Archaic Techniques of Ecstasy, Bollingen Series LXXVI, Princeton (Princeton University Press).

1978 - The Forge and the Crucible, Chicago (University of Chicago Press).

FAGAN, Brian

1974 - Men of the Earth, Boston (Little, Brown \& Company).

FRANKFORT, Henri

1978 - Kingship and the Gods, Chicago (University of Chicago Press).

GIEDION, Sigfried

1964 - The Eternal Present: The Beginnings of Architecture, Bollingen Series XXXV.6.II, New York (Pantheon).

GIMBUTAS, Marija

1974 - The Gods and Goddesses of Old Europe: 7000 to 3500 B.C.: Myths, Legends and Cult Images, Berkeley and Los Angeles (University of California Press).

GOVINDA, Lama Anagarika

1976 - The Psycho-Cosmic Symbolism of the Buddhist Stupa, Emeryville, California (Dharma Publishing).

GRAVES, Robert

1960 - The Greek Myths: 1 \& 2, Middlesex (Penguin Books).

LOBELL, Mimi

1977 - Spatial Archetypes, Quadrant, Volume 10, Number 2, pp 5-44.

1983 - Spatial Archetypes, ReVISION, Volume 6, Number 2, pp 69-82.

MELLAART, James

1975 - The Neolithic of the Near East, New York (Charles Scribner's Sons).

NEUMANN, Erich

1954 - The Origins and History of Consciousness, Bollingen Series XLII, Princeton (Princeton University Press). 
1955 - The Great Mother: An Analysis of the Archetype, Bollingen Series XLVII, Princeton (Princeton University Press).

PERRY, John Wier

1966 - Lord of the Four Quarters: Myths of the Royal Father, New York (Macmillan).

PIAGET, Jean

1960 - The Child's Conception of the World, Totowa, New Jersey (Littlefield, Adams \& Company).

PIAGET, Jean and BÄRBEL, Inhelder

1967 - The Child's Conception of Space, New York, (Norton).

PRICHARD, James B.

1969 - Ancient Near Eastern Texts, 3rd Edition with Supplement, Princeton (Princeton University Press).

RENFREW, Colin

1979 - Before Civilization: The Radiocarbon Revolution and Prehistoric Europe, Cambridge (Cambridge University Press).

ROWLAND, Benjamin

1970 - The Art and Architecture of India, Middlesex (Penguin).

SPENGLER, Oswald

1939 - The Decline of the West, New York (Alfred A. Knopf).

SCHWENK, Theodor

1965 - Sensitive Chaos, London (Rudolf Steiner Press).

THOMPSON, J. Eric S.

1970 - Maya History and Religion, Norman (University of Oklahoma Press).

TRUMP, D.H.

1980 - The Prehistory of the Mediterranean, New Haven (Yale University Press).

VOLWAHSEN, Andreas

1969 - Living Architecture: Indian, New York (Grosset \& Dunlap).

WENKE, R.J.

1980 - Patterns in Prehistory: Mankind's First Three Million Years, Oxford (Oxford University Press). 